\title{
Early Language Development of a Child with Expressive Language Disorder: A Parents' Narration
}

\author{
Dewi Rosmala ${ }^{1}$, Arini Nurul Hidayati ${ }^{1 *}$, Fuad Abdullah $^{1}$ \\ ${ }^{1}$ Universitas Siliwangi Tasikmalaya \\ dewi.rosmala@unsil.ac.id,*arininurul@unsil.ac.id, fuad.abdullah182@gmail.com
}

\begin{abstract}
Mainstream children generally experience typical stages throughout the milestones of their language development, from crying, cooing, babbling, until mature speech. Nevertheless, children with special condition usually have difficulties in getting through each phase of the development, such as those having expressive language disorder. These children usually encounter problems in communicating their needs and ideas verbally or non-verbally. This study attempts to present a story of the first five-year journey of Zaid's language development, a child with expressive language disorder. Through interview, observation, and documentation, the study informs that Zaid was a late talker and experience difficulties in structuring well-ordered sentences.
\end{abstract}

Keywords: Early language development, expressive language disorder, narrative inquiry.

\begin{abstract}
Abstrak
Anak-anak pada umumnya mengalami tahapan khas di sepanjang tonggak perkembangan bahasa mereka, dari tahap menangis, mendekur, meraban hingga tuturan yang matang. Namun, anak dengan kondisi khusus biasanya mengalami kesulitan dalam melewati setiap fase perkembangannya, seperti mereka yang mengalami gangguan bahasa ekspresif. Anakanak ini biasanya memiliki masalah dalam mengkomunikasikan kebutuhan dan idenya secara verbal maupun non-verbal. Melalui penelitian ini, penulis mencoba menyajikan sebuah narasi tentang perjalanan lima tahun pertama Zaid, seorang anak penyandang gangguan bahasa ekspresif. Melalui wawancara, observasi, dan dokumentasi, penelitian ini menginformasikan bahwa Zaid mengalami keterlambatan bicara pada tahap perkembangan awal bahasanya dan kesulitan merangkai kalimat dengan susunan gramatika yang baik.
\end{abstract}

Kata Kunci: tahapan perkembangan awal, gangguan bahasa ekspresif, penelitian naratif

\section{INTRODUCTION}

Parents require more effort to raise children with language disorders. The limitations of the children encourage them to put extra affection and attention to make sure that their children wellbeing is well-attended and provide treatments that support their growth. Even though it might lead the increase of stress level as the parents having children with language disorders (Siklos and Kerns, 2007; Rivard, Terroux, Parent-
Boursier, and Mercier, 2014; Krakovich, McGrew, Yu, and Ruble, 2016), they are still expected to scaffold their children to develop optimally amidst their limitations. Parents are also encouraged not to wrongly exploit their children's abilities. Instead of paying more attention to the children's limitations, other neglected abilities or intelligences might be potential to explore.

This article intends to file the story of a child with expressive language disorder from the parents' viewpoints. This aims at giving encouragement to other parents who 
experience similar issues or other parties having intensive contact with this type of children such as classroom teachers, therapists, siblings, or relatives. These children might experience diverse levels of difficulty in 'putting sentences together when talking' (Spooner, 2002, p. 290). Moreover, Chiat in Spooner (2002) proposes, "in order for children to express events in sentences, the relationship between events and verb argument structure is a key target. They must discover the verbs of the language, their forms and the events on which they focus. They must at the same time discover the arguments entailed by the verb ... and where those arguments go in relation to the verb" (p. 291). Meanwhile, children with expressive language disorder find it difficult to do such a way. Therefore, building an awareness and understanding on the children's condition is paramount in order to help them develop their language skills.

Previous study concerning the issue of children with expressive language disorder was conducted by Paul (1991). In this research, she depicts the profiles of toddlers with slow expressive language development through a longitudinal study conducted to children between 18 to 24 months of age whose parents reported small expressive vocabularies on the Language Development Survey (Rescorla, 1989). In the Indonesian contexts, the studies focusing on this issue are also getting into the limelight recently (see Merdiasi, Tiatri, Dewi, 2017; Fitriana, 2019; Hasiana, 2020; Kurniasari and Prima, 2020; Larasati, Bachtiar, and Jaya, 2021). Nevertheless, none of the research used narrative study as the research methodology. Therefore, the present study would put a certain emphasis on the language development of a child by utilizing the parents' stories using narrative inquiry as the research method. Zaid (pseudonym), the main actor of this story, is a five-year old boy diagnosed to have expressive language disorder at 4.9 years old which is projected to contract dyslexia in his later age. A long-shortened journey of how the language development of Zaid, a child with expressive language disorder, at his first five-year journey would become the heart of this study.

\section{Common Stages in Children's Language Development}

Even though there are different periods in reaching each milestone in the language development, many experts agree that all children would get through certain stages when acquiring language. Aitchison (2008) claims, there are nine phases that children usually pass. A normal child will cry a moment after the birth, and continue to develop their language ability. They start cooing at 6 weeks old and babbling at 6 months old. One-word utterances and twoword utterances are usually gained at the age of 1-1.5 years old. When they reach two years old, they will begin to inflect the words, question, and form negative sentences. The complex sentences generally appear at five years old and the mature speech is at the age of ten. Moreover, O'Grady (2003) informs that children would begin to produce their first word at the age of 1-1.4 years old and expand the numbers of vocabularies each and every day starting at 18 months old even until 18 years old and more.

\section{Defining Expressive Language Disorder}

A psychological condition of an individual that results in the occurrence of language impairment and impacts on their inability to convey verbal or written messages is amongst the definitions of expressive 
language disorder. If the common children have started to "exhibit communicative intentions by using gestures and nonconventional vocalizations and to call attention to themselves before they say their first words at age 12 months", children with expressive language disorder find it difficult to reach that stage (Paul, 1991, p. 2; Chapman, 1989). In the following stages of language development such as comprehending the meaning of the words which are commonly experienced three months before the production, these children will also find it very challenging (Paul, 1991). Even though there is no single consensus to define this condition, many researchers agree that children who experience language development disorders would perform distinctive behaviour since their early ages (see Richardson, Kulju, Nieminen, and Torvelainen, 2009; Hawa and Spanoudis, 2013). Therefore, these children need to diagnose as early as possible to get the remedial treatments.

\section{Characteristics of Children with Expressive Language Disorder}

Children with expressive language disorder are characterized by the complexion of words combination. Therefore, they get difficulties to form accurate phrases and sentences. For example, a child may not use the correct form of the verb tense (they might say 'I doed' when they mean 'I did') or they might neglect certain grammatical disputes (they say 'She watching' when they mean 'She is watching'). They typically produce much shorter phrases and sentences than other children of the same age, and their vocabulary (the number of words they know and use) is smaller and more basic. To decide whether a child performs a language delay, it is necessary to not only recognize the normal milestones of development, but also "the breadth of the normal range" (Paul, 1996). There are some indicators defining the expressive language disorder. Vocabulary size in the third year of life is amongst the parameter. Fensen, Dale, Reznick, Hartung, \& Burgess (1990) reported that average vocabulary size in normal children at 18 months of age is over 100 words, whereas the standard deviation in this measure is $111,102 \%$ of the mean. By 24 months, average vocabulary size is over 300 words, with a standard deviation of 175 , only $58 \%$ of the mean. The standard deviation in vocabulary size declines sharply between 18 and 24 months. This suggests that despite large variation, a normal range of vocabulary development can be meaningfully defined by 24 months, although probably not much earlier. Children whose expressive vocabularies contain fewer than 50 words can be seen as performing significantly below the average vocabulary size for their age at 24 months.

\section{METHOD}

This research is an interview-based study, a narrative inquiry that empowers the parents' experience in assisting their child with expressive language disorder getting through the phases of his language development. This is in line with Connelly and Clandinin (2006) which suggest that narrative inquiry makes use of experience as phenomenon under study. The participants of this study are Zaid and his parents. Zaid was born on August 27, 2015 and diagnosed as a child with expressive language disorder and potentially contract dyslexia at his later age. The diagnosis was stated by a paediatric as well as a neurodevelopmental scientist on May 25, 2020 when he was 4.9 years old. Zaid has nonpurposefully raised bilingually (Bahasa 
Indonesia and English), but his habit of watching videos in English has triggered his interests towards English. Therefore, both his father and mother frequently switch languages when talking to him. His father (Akbar, pseudonym) works as a civil engineer in an international construction company and his mother (Hilma, pseudonym) is an English teacher. They are 37 years old and 32 years old, respectively. Both are frequently speaking English in their workplace and at home.

The interviews were conducted to Zaid's parents from August - November 2020 to recall their memories of how Zaid's language has been developing. Moreover, in order to fulfil the data triangulation requirements in the qualitative study, observation and documentation were also conducted. Observation was conducted to see Zaid's language activities from August - November 2020 (after the diagnosis) and the documents were gained from 23 videos collected by Zaid's parents since he was born to witness the language development of Zaid by periods. The collected data was analyzed using narrative analysis and displayed thematically to indicate the emerging phenomena appeared from Zaid's parents' experiences (Labov, 1997; Braun and Clarke, 2006; Esin, 2011).

\section{FINDINGS AND DISCUSSION}

\section{Findings}

The following table illustrates the different language achievement of Zaid and other common children. This illustration depicts the decrease of communication ability at the age of 1 year old.

\begin{tabular}{|l|c|c|}
\hline $\begin{array}{c}\text { Milestones of } \\
\text { Children's } \\
\text { language } \\
\text { development }\end{array}$ & $\begin{array}{c}\text { Common } \\
\text { Children }\end{array}$ & Zaid \\
\hline Crying & Birth & New-born \\
\hline Cooing & 6 weeks old & 6 weeks old \\
\hline Babbling & 6 months old & 6 months old \\
\hline $\begin{array}{l}\text { Intonation } \\
\text { Patterns }\end{array}$ & 8 months old & 8 months old \\
\hline $\begin{array}{l}\text { One-word } \\
\text { utterances }\end{array}$ & 1 year old & 2.7 years old \\
\hline $\begin{array}{l}\text { Two-word } \\
\text { utterances }\end{array}$ & 18 months old & 3 years old \\
\hline $\begin{array}{l}\text { Word } \\
\text { inflections }\end{array}$ & 2 years old & 5 years old \\
\hline $\begin{array}{l}\text { Questions, } \\
\text { negatives }\end{array}$ & 2.5 years old & 5 years old \\
\hline $\begin{array}{l}\text { Rare of } \\
\text { complex } \\
\text { constructions }\end{array}$ & 5 years old & \multicolumn{1}{|c|}{ - } \\
\cline { 1 - 3 } & &
\end{tabular}

(Aitchison, 2008)

\section{A cheerful yet less focused infant}

At the fourth year of marriage, Akbar and Hilma finally had their first child. The whole family was super delighted to hear the crying baby in the $\mathrm{C}$-section room. This baby, Zaid, has grown up similarly to his peers until his first year. He responded to any stimulus given by the adults; having responsive eye contacts towards sounds and movements, frequently spreading smiles when people invited him to play. He also performed cooing at the age of six weeks old and babbling at six months old. He was also able to imitate the sounds he heard; making intonation patterns at the age of 8 months old. In short, Zaid had followed the common language stage at his earliest phase of life.

As a working mother living far away from her husband, Hilma had limited time to spend and play with Zaid. She hired a baby sitter to take care of his son while she was away. As a result, Zaid oftentimes played himself busy with the gadgets whenever his mom at work. Zaid showed a different attitude at the age of 1.5 years old. 
He was not as responsive as earlier and tended to ignore other people's greetings and instructions. Soon after this attitude's change, Hilma realized that Zaid has performed several autistic symptoms. For instance, he frequently flapped his hands when he was too excited about something; e.g., watching his favourite TV shows or seeing a moving object. Moreover, Zaid has also not produced any words yet at this age. He was not able to express his needs and ideas and unable to point to certain things he expected. Understanding an uncommon condition, Akbar and Hilma saw a psychologist in their town. After conducting a brief observation, Zaid was suspected to have ASD (Autism Spectrum Disorder), a developmental disability which causes significant social, communication, and behavioural challenges. It was signed by the decrease of communication skills. Therefore, Akbar and Hilma decided to give an early intervention through therapy classes offered by an applied psychologist institution. The classes did not last long since Zaid kept crying and denying anytime his parents took him to the therapy place. Finally, after six months therapy, his parents decided to retract him from the therapy clinic and intervened themselves at home.

\section{Excitement in numbers and alphabets}

When the happy Zaid had reached his two years old, no words had uttered yet. His parents always tried to attract his attentions by various toys they bought for him. There were only two things interested him persistently; anything containing alphabets and numbers. Therefore, Hilma introduced him to the things around using bilingual flash cards with their letters. Even though she realized that it was too early to introduce him reading, she just followed her instinct as an attempt to make Zaid speak. Zaid started to focus anytime his mother taught him how to pronounce alphabets (from $\mathrm{A}$ to $\mathrm{Z}$ ) and numbers (from 1 to 10 ). Also, when his mom mentioned names of fruits in bahasa Indonesia (apel, jeruk, manga, papaya, alpukat, and pisang) animals (kucing, anjing, ayam, kecoa, cicak, nyamuk), vegetables (bayam, wortel, kubis, kol, kacang merah), family members (ayah, ibu, kakek, nenek, paman, bibi), vehicles (mobil, motor, sepeda, becak) and things in the house (piring, sendok, televisi, cermin), Zaid always put his attention. Unfortunately, Zaid did not want to repeat what his mother said. He was just listened and sometimes flapped his hands since he was too excited. These activities became a daily habit for about three months.

Independent intervention given by Hilma has proven to result in a positive impact. Hilma spent more time to play with Zaid. She even moved to a house closer to her workplace, so that she could have more chances to meet Zaid. She believes that the best therapist for his child is his own mother. Even though Zaid's focus has been still easy to distract, at least, Zaid recognized the person he wanted to ask for help. Feeling unsatisfactory, at the age of 2.5, Akbar and Hilma took Zaid to an international hospital in Yogyakarta to conduct a further diagnosis. After a threehour observation, Zaid was not diagnosed as an autistic child, rather, the symptoms were closer to PDD-NOS (Pervasive Developmental Disorder - Not Other Specified), the experts said. This means that the condition of Zaid at this age is milder that those contracting ASD (Autism Spectrum Disorder) since there were some characteristics that did not meet the criteria of being an autistic. This condition is characterized by impairment in the development of social interaction, 
verbal and non-verbal communication, imaginative activity and a limited number of interests and activities that tend to be repetitive. Knowing the autistic symptoms degraded, Hilma continued to conduct her independent intervention at home. With the help of her mother and one baby sitter, she could find the coping strategies to manage the therapy for her child.

\section{“Apple” was Zaid's first word}

When reaching 2.7 years old, Zaid produced his first word, which was "Apple". His parents and grandparents were shocked by his ability to pronounce the word like an English native speaker. This achievement most likely happened due to the gadgets' influence. He mentioned this word for days and was so enthusiastic with his achievement. Trying to immerse to his world, Hilma encouraged him to mention other fruits' names in English (orange, mango, banana, papaya, grapes, mangosteen, avocado, and others) and Zaid could perfectly mention one by one after given example by his mom. Uniquely, Zaid did not want to say the words in Bahasa Indonesia. $\mathrm{He}$ preferred English pronunciation and would be silent when his mother gave example in Bahasa Indonesia. Therefore, at the beginning, Hilma tried to follow her child's interests. Giving some more flash cards and bombarding his memories with hundreds of vocabularies became her new daily job since then. Being aware that the daily communication language in the surrounding is Bahasa Indonesia, Hilma switches the language to introduce Zaid new vocabularies in Bahasa Indonesia. For example, she said:

"This is an orange (Ini jeruk)."

"The colour is orange. (Warnanya oranye)."
"Zaid loves eating orange and banana. (Zaid suka makan jeruk dan pisang)."

Zaid was eventually excited in the method and asked Hilma to translate every new word he found into the opposite language (English- Bahasa Indonesia). He has been able to pronounce more than 1000 English words in three months but still less than 300 words of Bahasa Indonesia. At the age of three, he has been able to read complex paragraphs in a book. He even has a tendency to like reading adult thick books such as encyclopaedia, dictionaries, holy book (Al-Qur'an), and scientific books compared to the books for his age.

Although Zaid grew up as a fast reader, Hilma was still confused about why Zaid was still difficult to conduct any transactional conversations with his peers. Three paediatrics suggested visiting a professional in the area of children growth and development in Bandung, the capital city of West Java province. Without any further ado, Zaid's parents contacted the clinic and registered their son to make appointment with the doctor. Very unluckily, since this place is considered as the most-visited centre for children with similar issues, Zaid had a chance to see the doctor after almost two years in queue. At the age of 4.9 years old, his parent eventually had an opportunity to consult with the doctor virtually. At this virtual meeting, the doctor has predicted that Zaid had an expressive language disorder which might potentially contract dyslexia. The doctor continued the explanation about misperception of the previous diagnoses claiming that Zaid had ASD or PDD-NOS. Many experts considered those language pathologies were similar, in fact, they were all distinctive from one another, said the doctor. Shortly, the last diagnosis mentioned that Zaid would not experience general learning difficulties as those 
contracting ASD and PDD-NOS, rather he would simply have specific learning difficulties.

\section{[Where is my] dictionary, Mom?}

Due to the pandemic situation in 2020, the intervention was postponed and the doctor treated Zaid with medication to commence the therapy. Zaid showed a significant difference after three months treatment using such medication; his focus began to improve much better. He could stare the interactants' eyes until more than twentyfive seconds and he has started to communicate with the people around. Although the ability to convey needs and ideas was still below the average child at his age, he always showed improvement each and every day. He used keywords or incomplete sentences to communicate and was still not able to arrange a wellorganized sentence. Moreover, he also tended to repeat, memorize, and echo the speaker's sentences instead of ordering the sentences by himself. Here are some examples of the 'sentences' he uttered:

The keywords and incomplete sentences,

$$
\begin{aligned}
& \text { "[...] dictionary, Mom? } \\
& \text { "[...] story. [...] want [...] story." } \\
& \text { "[...] give }[\ldots] \text { book." } \\
& \text { "[...] wanna eat with egg and } \\
& \text { rice." }
\end{aligned}
$$

The echoed sentences,

$$
\begin{aligned}
& \text { "Hasan, let's play jumping with } \\
& \text { Zaid." } \\
& \text { "Mimi, please don't go to work. Play } \\
& \text { with me." } \\
& \text { "Mimi works in a university. Mimi } \\
& \text { goes to work by car." }
\end{aligned}
$$

Those examples made Hilma realized that Zaid got difficulties in comprehending the meaning of the words and sentences that he has been able to pronounce. At the age of five, he has been very fluent in reading books both in English and Bahasa Indonesia, he even reads Al-Qur'an in the Arabic language. However, he simply easily reads the forms of the sentences without getting adequate comprehension on the texts.

\section{Discussion}

\section{A Late Talker: An Early Sign of Expressive Language Disorder}

Understanding that common children experience certain stages in acquiring language, when finding anomalies, parents must be aware. For instance, infants under one year old started cooing at the age of three months old and babbling at the age of 5-6 months old; at this early stage, they are able to distinguish sounds and understand simple instructions. At the next stage, they start to produce their first word at the age of 1-1.4 years old and expand the numbers of vocabularies each and every day starting at 18 months old even until 18 years old and more (Elimas in Gleason, 1985; Dardjowodjodjo, 2005, O'Grady, 2006). These orderly phases cannot always be identified in children with expressive language disorder which tend to talk later than the average kids. This "developmental language disorders are characterized by a maturational trajectory that deviates or lags that of normal children" (Leonard and Eckert, 2008, p. 663). Some of the writers addressed the children with this condition as the "late-talkers, late talking young children, or late-talking toddlers" (Paul, 1991; Paul, Hernandez, Taylor, and Johnson, 1996; Paul, Murray, Clancy, and Andrews, 1997). Learning the story of Zaid as a late talker, he was actually got through 
the cooing and babbling stage at his early life, but had lost the ability to follow the later stage which was word production. " 'Late talkers' is a term used in the scientific field of atypical language development to describe toddlers who exhibit delay in expressive language skills, although they do have intact receptive skills" (Hawa and Spanoudis, 2013, p. 400). Irwin, Carter, and Briggs-Gowan (2002) pointed out that early difficulties in expressive language are linked with poor social-emotional adjustment. This would result in the inability to engage with other children or people around. Moreover, children with language disorder are also at risk with problems in social adaptation and learning at school, since 'language comprehension, production, and use are fundamental to social and academic success' (Bashir and Scavuzzo, 1992 p. 53). Therefore, it is essential to choose the best education system to develop their potentials.

\section{Difficulties in ordering well-structured sentences}

In terms of grammatical ability, Zaid performed a 'pivot grammar' with linear relationship between constituents and specification of a small class of forms which occurred in pivotal constructions with a large class of lexical constituents (Bloom, 1968). The inability to construct a well-organized sentence has resulted in poor social skills which might 'particularly vulnerable to disruption in children with late expressive language development, even after communication skills have moved into the normal range' (Paul, Looney, and Dahm, 1991, p. 858). Similarly, they would have expressed significantly fewer intentions in relation to the communicative initiations with their interlocutors (Paul and
Shiffer, 1991). As mentioned earlier, deficits in social skills might accompany expressive delay. This deceptive probability is based on theoretical discussions of language as a primary means for engaging in social intercourse (Anglin, 1980; Garvey, 1984), and on empirical findings (Paul \& Shifter, 1987) that toddlers in their sample made fewer verbal and non-verbal attempts than normally speaking peers to initiate social communication (Paul and Shiffer, 1991).

\section{CONCLUSION}

The milestones of children with expressive language disorder might differ from the mainstream children due to the language impairment they possess. The inability to convey oral messages might or might not be influenced by the difficulty of understanding the receptive language. The case of Zaid illustrates the condition of a child with expressive language disorder and has no difficulties in transmitting the forms of the vocabularies and sentences and receiving verbal language. $\mathrm{He}$ could perfectly mention the words with adequate pronunciation and spelling. However, his difficulties placed on putting those words contextually and lack ability to digest the meanings of the utterances. Practically speaking, as this psychological condition is considered a spectrum, every child might perform different symptoms. Therefore, it is necessary to identify the condition earlier to implement intervention as soon as possible.

Supports from the surrounding are very crucial in developing the children's language skills, especially the parents who have the closest string with the children. They extremely need to educate themselves, learn how to plan proper interventions for their children by considering the children's interests. Building proximity between parents and children is also another pivotal 
aspect to grow the children's trust on the parents. When the children trust the parents, they will be easier to be directed. This research has a lot of weaknesses, especially in providing the sufficient literature to support the findings. Therefore, the further research could expand on the literature study or corpus study in the area of expressive language disorder or bilingualism in children with expressive language disorder. Furthermore, more stories are also encouraged to report in the future articles to expand the information in some diverse spectrums of expressive language disorder with its comorbidities.

\section{ACKNOWLEDGEMENT}

This paper is dedicated to the beloved one, HSR, for his everlasting inspiration and affection. You are truly loved.

\section{REFERENCES}

Aitchison, J. (2008). Lifting the veil: Uncovering language origin. Unity and diversity of languages, Amsterdam: Benjamins, 17-28.

Anglin, J. M. (1980). Acquiring linguistic skills: A study of sentence construction in preschool children. In D. R. Olson (Ed.), The social foundations of language and thought (pp. 111-186). New York: W. W. Norton.

Bashir, A. S., \& Scavuzzo, A. (1992). Children with language disorders: Natural history and academic success. Journal of learning disabilities, 25(1), 53-65.

Bloom, L. M. (1968). Language development: Form and function in emerging grammars. Dissertation: Columbia University.

Braun, V., \& Clarke, V. (2006). Using thematic psychology. Qualitative research in psychology, 3(2), 77-101.

Chapman. R. (1981). Exploring Children's Communicative Intentions. In $\mathrm{J}$. Miller (Ed), Assesing language production in children: Experimental procedures. Baltimore, MD: University Park Press.

Connelly, F. M., \& Clandinin, D. J. (2006). Narrative inquiry. Handbook of complementary methods in education research, 3, 477-487.

Dardjowidjojo. (2006). Psikolinguistik: Pengantar Pemahaman Bahasa Manusia. Jakarta: Yayasan Pustaka Obor Indonesia.

Esin, C. (2011). Narrative analysis approaches. Qualitative research methods in psychology. Combining core approaches, 92-117.

Fensen, L., Dale, P., Reznick, J., Thal, D., Bates, E., Hartung, J., Pethick, S., \& Reilly, J. (1993). MacArthur Communicative Development Inventories. San Diego: Singular Publishing Group

Fitriana, S. (2019). Kurangnya bahasa ekspresif pada anak usia 5 tahun di Jl. Raden Fatah No 004 Rt 01 Kelurahan Pagar Dewa, Kecamatan. Selebar Kota Bengkulu. Al Fitrah: Journal of Early Childhood Islamic Education, 2(2), 309-321.

Garvey, C. (1984). Children's talk. Cambridge: Harvard University Press.

Gleason, J. B. (1985). The Development of Language. Ohio: Merill Publishing.

Hawa, V. V., \& Spanoudis, G. (2014). Toddlers with delayed expressive language: An overview of the characteristics, risk factors and language outcomes. Research in 
developmental disabilities, 35(2), 400-407.

Hasiana, Isabella. Studi kasus anak dengan gangguan bahasa reseptif dan ekspresif. SPECIAL: Special and Inclusive Education Journal 1.1 (2020): 59-67.

Merdiasi, D., Tiatri, S., \& Dewi, F. I. (2017). Penerapan milieu teaching dalam meningkatkan kemampuan bahasa ekspresif pada anak yang mengalami keterlambatan bahasa. Inspiratif Pendidikan, 6(2), 344-354.

Irwin, J. R., Carter, A. S., \& Briggs-Gowan, M. J. (2002). The social-emotional development of "late-talking" toddlers. Journal of the American Academy of Child \& Adolescent Psychiatry, 41(11), 1324-1332.

Krakovich, T. M., McGrew, J. H., Yu, Y., \& Ruble, L. A. (2016). Stress in parents of children with autism spectrum disorder: An exploration of demands and resources. Journal of autism and developmental disorders, 46(6), 2042-2053.

Kurniasari, A., \& Prima, E. (2020). Penanganan anak usia dini dengan gangguan perkembangan bahasa ekspresif di KB Al Azkia Lab Fakultas Tarbiyah dan Ilmu Keguruan Iain Purwokerto. Jurnal CARE (Children Advisory Research And Education), 8(1), 20-39.

Labov, W. (1997). Some further steps in narrative analysis. Journal of narrative and life history, 7, 395415.

Larasari, P. A., Bachtiar, I. G., \& Jaya, I. (2021). Meningkatkan Kemampuan Bahasa Ekspresif pada Anak dengan Autisme Melalui Media Lotto Bergambar. Jurnal Penelitian Pendidikan Khusus, 9(1), 105-112.
Leonard, C. M., \& Eckert, M. A. (2008). Asymmetry and dyslexia. Developmental neuropsychology, 33(6), 663-681.

O'Grady, W. (2006). The problem of verbal inflection in second language acquisition. In Proceedings of the Conference of the Pan-Pacific Association of Applied Linguistics (pp. 169-190).

Paul, R. (1991). Profiles of toddlers with slow expressive language development.Topics in Language Disorders 11.4.1-13.

Paul, R., \& Shiffer, M. E. (1991). Communicative initiations in normal and late-talking toddlers. Applied Psycholinguistics, 12(4), 419-431.

Paul, R. (1996). Clinical implications of the natural history of slow expressive language development. American Journal of Speech-Language Pathology, 5(2), 5-21.

Paul, R., Hernandez, R., Taylor, L., \& Johnson, K. (1996). Narrative development in late talkers: Early school age.Journal of Speech, Language, and Hearing Research, 39(6), 1295-1303.

Paul, R., Murray, C., Clancy, K., \& Andrews, D. (1997). Reading and metaphonological outcomes in late talkers. Journal of Speech, Language, and Hearing Research, 40(5), 1037-1047.

Rescorla, L. (1989). The Language Development Survey: A screening tool for delayed language in toddlers. Journal of Speech and Hearing disorders, 54(4), 587-599.

Richardson, U., Kulju, P., Nieminen, L., \& Torvelainen, P. (2009). Early signs of dyslexia from the speech and language processing of children. International journal of 
speech-language pathology, 11(5), 366-380.

Rivard, M., Terroux, A., Parent-Boursier, C., \& Mercier, C. (2014). Determinants of stress in parents of children with autism spectrum disorders. Journal of autism and developmental disorders, 44(7), 1609-1620.

Salamah, S. (2015). Studi Ringkas Pemerolehan Bahasa Pada Anak. PBSI FKIP Universitas Ahmad Dahlan Yogyakarta. Bahastra, 33(2), 73-82.

Spooner, L. (2002). Addressing expressive language disorder in children who also have severe receptive language disorder: A psycholinguistic approach. Child Language Teaching and Therapy, 18(3), 289-313. 